\title{
Prospective cohort study in relation of placental location and risk of developing preeclampsia in a tertiary care hospital
}

\author{
Raji C. ${ }^{1}$, Asha Sundaram ${ }^{2}$, Shenbagam G. ${ }^{1 *}$
}

\begin{abstract}
${ }^{1}$ Department of Obstetrics and Gynaecology, Government Medical College, Pudukottai, Tamil Nadu, India
${ }^{2}$ Government Hospital, Devakottai, Tamil Nadu, India
\end{abstract}

Received: 20 January 2022

Accepted: 05 February 2022

\section{*Correspondence:}

Dr. Shenbagam G.,

E-mail: drshenba91@gmail.com

Copyright: (C) the author(s), publisher and licensee Medip Academy. This is an open-access article distributed under the terms of the Creative Commons Attribution Non-Commercial License, which permits unrestricted non-commercial use, distribution, and reproduction in any medium, provided the original work is properly cited.

\begin{abstract}
Background: Preeclampsia is one of the leading and unpredictable causes of maternal morbidity and mortality. This study was done to find the association between location of placenta and the development of preeclampsia as well as its correlation with severity of preeclampsia.

Methods: This prospective cohort study was conducted in government medical college hospital, Pudukottai, Tamil Nadu, India between March 2021 to December 2021. The 150 pregnant women were registered in this study. The location of the placenta was determined by ultrasound at 18-24 weeks. The placenta was classified as central and lateral. The endpoint of the study was the development of hypertension or delivery.

Results: The incidence of preeclampsia was $32 \%$. Primigravida was a significant high-risk factor. Preeclampsia was more common in 20-25 years $(52.1 \%)$. Among 48 women who developed preeclampsia, 32 had lateral location of placenta and 16 had central location of placenta. Lateral location of placenta in predicting preeclampsia, $\mathrm{p}<0.0001$, which is clinically significant. Lateral location of placenta has high incidence of both severe $66.7 \%$ and non-severe preeclampsia $67.6 \%$. The sensitivity- $66.6 \%$, specificity- $78.4 \%$, positive predictive value-59.2\%, negative predictive value- $83.3 \%$ and the likelihood ratio of 3.09 of our study are significant.

Conclusions: This study shows that placental location determined by ultrasonogram between 18-24 weeks of gestation is an excellent screening tool for the prediction of pre-eclampsia. Lateral placentation helps to identify who are at greatest risk and those requiring careful obstetric management to achieve a more favourable outcome and to decrease the maternal and perinatal morbidity and mortality with preeclampsia.
\end{abstract}

Keywords: Preeclampsia, Placental laterality, Central placenta

\section{INTRODUCTION}

Hypertensive disorders complicate $5-10 \%$ of all pregnancies and together they are one of the deadly triads that contribute greatly to maternal morbidity and mortality rates. $^{1}$ Of hypertensive disorders, the preeclampsia syndrome, either alone or superimposed on chronic hypertension is the most dangerous. ${ }^{1}$ Preeclampsia is a complex clinical syndrome involving multiple organ systems and still remains the principal cause of maternal and perinatal mortality and morbidity. Incidence of preeclampsia is commonly cited to be about 5\%.1,2 Preeclampsia occurs only in the presence of placenta.
Incidence is influenced by parity, race and genetic factors. $^{4,5}$ According to $\mathrm{WHO}$, in developed countries, $16 \%$ of maternal deaths were attributed to hypertensive disorders. ${ }^{1}$ Maternal mortality due to hypertensive disorders in India ranges from $2-30 \%$. 6,7

FOGSI and other studies shows incidence of preeclampsia in India ranges $11-13 \% .^{8}$ Preeclampsia is a multiorgan disease process of unknown aetiology characterised by de novo development of hypertension and proteinuria after 20 weeks of gestation. It is a pregnancy specific syndrome that can affect virtually any organ system. 
Conventional mercury sphygmomanometer is the gold standard for blood pressure measurement. ${ }^{9} \mathrm{~A}$ fetus is not a requisite for preeclampsia to develop. And although chorionic villi are essential, they need not be intrauterine, as preeclampsia can develop with an abdominal pregnancy by Worley et al. ${ }^{10}$ The concept of vasospasm with preeclampsia has been advanced for a century by Volhard. ${ }^{11}$ Various biological markers implicated in the preeclampsia syndrome have been measured to help in preventing its development. A number of mechanisms have been proposed to explain the cause of preeclampsia, among which placental implantation with abnormal trophoblastic invasion of uterine vessels is currently considered important. The search for an ideal predictive test and preventive measure remains challenging.

Among the various predictors for preeclampsia, the placental location by ultrasound at $18-24$ weeks is very cost-effective, non-invasive and has a good positive predictive value. ${ }^{12}$ It is possible that when the placenta is centrally located, the uteroplacental blood flow needs are met by equal contribution from both the uterine arteries. However, when the placenta is laterally located, in the majority of patients the uteroplacental blood flow needs are to be met primarily by one of the uterine arteries, with some contribution by the other side via collaterals. In the women with centrally located placenta, both uterine arteries demonstrate similar resistance. ${ }^{13,15}$ In laterally located placenta, the uterine artery close to the placenta has lower resistance than the one opposite from it and the uteroplacental blood flow needs to be met primarily by one of the uterine arteries with some contribution by the other uterine artery via collateral circulation. ${ }^{13,14}$ The degree of collateral circulation may not be the same in all women and deficient contribution facilitates the development of preeclampsia. ${ }^{16}$ Screening the population in search for disease at its earlier stages, is a logical extension in the role of preventive medicine. If we wish to prevent such disorder, we must seek ways of preventing or ameliorating the disease process. In preventing this disorder, the most important factor is lack of timely prediction. Various biological markers implicated in the preeclampsia syndrome have been measured to help predict its development. Although most have been evaluated in the first half of pregnancy, some have been tested as predictors of severity in the third trimester according to Mosimann et al. ${ }^{17}$ The ability to predict those women at risk for preeclampsia in very early pregnancy might decrease maternal and fetal morbidity through closer surveillance and early intervention. Determination of placental position by ultrasonogram at $18-24$ weeks is also a highly sensitive test for prediction of preeclampsia by Kofinas et al. ${ }^{18}$

\section{Aim of the study}

The aim was to study relationship between the placental location determined by ultrasonogram at 18-24 weeks and development of preeclampsia and severity of preeclampsia.

\section{METHODS}

This Prospective cohort study was conducted between March 2021 and November 2021 at the department of obstetrics and gynaecology, government medical college, Pudukottai, Tamil Nadu, India. The 150 pregnant women attending the antenatal clinic at government medical college, Pudukottai were registered in this study. Inclusion criteria were Singleton pregnancy, gestational age between 18-24 weeks and those patients who are willing for follow up. Exclusion criteria were gestational age $<18$ and $>24$ weeks, multiple pregnancy, uterine anomalies, chronic hypertension, diabetes mellitus, renal disease, severe anaemia, thyrotoxicosis, Rh-incompatibility, connective tissue disorder and positive lupus anticoagulant.

A written informed consent was obtained from all the pregnant women included in the study. No dietary alterations were recommended. Detailed history was taken. Complete examination was done which included general examination, clinical examination of cardiovascular system, respiratory system, central nervous system and obstetric examination. Blood pressure was recorded in sitting posture and phase Korotkoff $\mathrm{V}$ sound was taken to determine the diastolic component. Basic investigations of haemoglobin, blood grouping and $\mathrm{Rh}$ typing, platelet count, blood urea, serum creatinine, SGOT, SGPT and urine-albumin were done. The location of the placenta was determined by ultrasound at 18-24 weeks in all 150 women. The placenta was classified as central when it was equally distributed between the right and the left side of the uterus irrespective of anterior, posterior or fundal position. When $75 \% /$ more of the placental mass was to one side of midline, it was classified as unilateral right or left placenta. The endpoint of study was the development of hypertension as per ACOG criteria or delivery. Followed up with routine antenatal visits for signs, symptoms of pre-eclampsia by routine examination of blood pressure, serial weight and investigation of preeclampsia when required and results were tabulated.

The outcome has been analysed with respect to age, parity, placental location, severe and non-severe preeclampsia, Incidence of HELLP syndrome and severity of proteinuria. Data were entered in the excel spread sheet and variables were coded accordingly. The statistical analyses were performed using Graph pad Prism version 5 software. Data were presented as frequency with proportion $\mathrm{n}(\%)$ for categorical. Fisher's exact test (for sample<30) was used to compare the proportions between groups as appropriate. $\mathrm{P}<0.05$ was considered statistically significant.

\section{RESULTS}

Preeclampsia is more common in the age group of 20-25 years with a frequency of $52.1 \%$ and primigravida was found to be a significant high-risk factor with the incidence of preeclampsia in our study is $32 \%$ (Table 1). Central location of placenta was more common in $96(64 \%)$ patients whereas lateral location in 54 patients (Table 2). 
Both central and lateral location of placenta is more common in 20-25 year (Table 3). No significant differences in incidence of placental location in relation to gravida (Table 4). Among the 48 women who developed preeclampsia, 32 women had lateral location of placenta and 16 women had central location of placenta (Table 5). In our study, lateral location of placenta in predicting preeclampsia, $\mathrm{p}<0.0001$, which is clinically significant. The relative risk with $95 \% \mathrm{CI}$ in our study shows that women with lateral location of placenta have 3.5 times more the risk of developing preeclampsia than women with central location of placenta (Table 6). Women with lateral location of placenta had high incidence of both severe $(66.7 \%)$ and non-severe preeclampsia $(67.6 \%)$ and among 48 cases, $13(27.1 \%)$ developed imminent symptoms (Table 7). The incidence of HELLP syndrome in study was $10.8 \%$ (Table 8). Statistically, significance difference was noted in development of preeclampsia in laterally located placenta (Table 9). Sensitivity-66.6\%, specificity-78.4\%, PPV-59.2\%, NPV-83.3\% and likelihood ratio of 3.09 of study are the significant (Table 10).

Table 1: Distribution of age and gravida.

\begin{tabular}{|c|c|c|c|c|c|c|c|c|c|}
\hline \multirow{2}{*}{$\begin{array}{l}\text { Age } \\
\text { (Years) }\end{array}$} & \multicolumn{2}{|c|}{ Study population } & \multicolumn{2}{|c|}{ Preeclampsia } & \multirow{2}{*}{ Gravida } & \multicolumn{2}{|c|}{ Study population } & \multicolumn{2}{|c|}{ Preeclampsia } \\
\hline & $\mathbf{N}$ & $\%$ & $\mathbf{N}$ & $\%$ & & $\mathbf{N}$ & $\%$ & $\mathbf{N}$ & $\%$ \\
\hline$<20$ & 12 & 8 & 7 & 14.6 & Primi & 51 & 34 & 17 & 35.4 \\
\hline $20-25$ & 91 & 60.6 & 25 & 52.1 & Gravida 2 & 24 & 32 & 13 & 27.1 \\
\hline $26-30$ & 37 & 24.7 & 12 & 25 & Gravida 3 & 25 & 34 & 18 & 37.5 \\
\hline$>30$ & 10 & 6.7 & 4 & 8.3 & & & & & \\
\hline Total & 150 & 100 & 48 & 32 & Total & 150 & 100 & 48 & 100 \\
\hline
\end{tabular}

Majority were in the age group of 20-25years and most are primi and third gravida, incidence of preeclampsia was $32 \%$

Table 2: Type of placental location, $(n=150)$.

\begin{tabular}{|lll|}
\hline Type of placental location overall & N & Percentage (\%) \\
\hline Central location & 96 & 64 \\
\hline Lateral location & 54 & 36 \\
\hline Total & 150 & 100 \\
\hline
\end{tabular}

The $96(64 \%)$ had central location of placenta and $54(36 \%)$ had lateral location of placenta.

Table 3: Type of placental location with respect to age.

\begin{tabular}{|lllll|}
\hline Age $($ Years $)$ & Central location, $(\mathbf{n = 9 6 )}$ & $\mathbf{2}$ & $\mathbf{N}$ & $\mathbf{\%}$ \\
\hline $\mathbf{< 2 0}$ & $\mathbf{N}$ & 4.2 & 8 & 14.8 \\
\hline $\mathbf{2 0 - 2 5}$ & 4 & $70.8^{*}$ & 23 & $42.6^{*}$ \\
\hline $\mathbf{2 6 - 3 0}$ & 68 & 23.96 & 14 & 25.9 \\
\hline $\boldsymbol{> 3 0}$ & 23 & 1.04 & 9 & 16.7 \\
\hline Total & 1 & 100 & 54 & 100 \\
\hline
\end{tabular}

The incidence of central and lateral location of placenta was higher among 20-25 years.

Table 4: Type of placental location with respect to gravida.

\begin{tabular}{|lllll|}
\hline Gravida & Central location, $(\mathbf{n = 9 6})$ & Lateral location, $(\mathbf{n = 5 4 )}$ & \% \\
\hline Primigravida & $\mathbf{N}$ & $\mathbf{\%}$ & 22 & 40.7 \\
\hline Gravida 2 & 29 & 30.2 & 14 & 26 \\
\hline Gravida 3 & 34 & 35.4 & 18 & 33.3 \\
\hline Total & 33 & 34.4 & 54 & 100 \\
\hline
\end{tabular}

Fisher's exact test was used. There was no significant difference $(\mathrm{p}=0.514)$.

Table 5: Comparison of risk of developing preeclampsia with gravida.

\begin{tabular}{|lllll|}
\hline & Patient developed preeclampsia, $(\mathbf{n = 4 8 )}$ & \multicolumn{2}{l|}{ Patient not developed preeclampsia, $(\mathbf{n = 1 0 2})$} \\
\hline Primigravida & $\mathbf{N}$ & $\mathbf{\%}$ & $\mathbf{N}$ & $\mathbf{\%}$ \\
\hline Gravida 2 & 17 & 35.4 & 34 & 33.3 \\
\hline Gravida 3 & 13 & 27.1 & 35 & 34.3 \\
\hline Total & 18 & 37.5 & 33 & 32.4 \\
\hline
\end{tabular}

Fisher's exact test was used and no significant difference was noted $(\mathrm{p}=0.66)$. 
Table 6: Relationship between the placental location and development of preeclampsia.

\begin{tabular}{|lllll|}
\hline Variables & $\begin{array}{l}\text { Patient developed } \\
\text { preeclampsia }(\mathbf{n = 4 8 )}\end{array}$ & $\begin{array}{l}\text { Patient not developed } \\
\text { preeclampsia, }(\mathbf{n = 1 0 2})\end{array}$ & P value & $\begin{array}{l}\text { Relative risk with } \\
95 \% \text { CI }\end{array}$ \\
\hline $\begin{array}{l}\text { Lateral location of } \\
\text { placenta, }(\mathbf{n = 5 4 )}\end{array}$ & 32 & 22 & $<0.0001 *$ & $3.5(2.1$ to 5.8$)$ \\
$\begin{array}{l}\text { Central location of } \\
\text { placenta, }(\mathbf{n = 9 6 )}\end{array}$ & 16 & 80 & & \\
\hline
\end{tabular}

Women with lateral location of placenta was significantly associated with the development of preeclampsia. $*$ indicates $\mathrm{p}<0.05$ and considered statistically significant. $\mathrm{CI}=$ Confidence interval. The $\mathrm{p}<0.0001$ which is statistically significant. Relative risk with $95 \% \mathrm{CI}$ shows that women with lateral location of placenta have 3.5 times the risk of developing preeclampsia.

Table 7: Comparison of severity of preeclampsia and development of imminent symptoms with type of placental location.

\begin{tabular}{|c|c|c|c|c|c|c|c|c|}
\hline \multirow{2}{*}{$\begin{array}{l}\text { Location of } \\
\text { placenta }\end{array}$} & \multicolumn{2}{|c|}{$\begin{array}{l}\text { Severe } \\
\text { preeclampsia }\end{array}$} & \multicolumn{2}{|c|}{$\begin{array}{l}\text { Non-severe } \\
\text { preeclampsia }\end{array}$} & \multicolumn{2}{|c|}{$\begin{array}{l}\text { Developed imminent } \\
\text { symptoms }\end{array}$} & \multicolumn{2}{|c|}{$\begin{array}{l}\text { Not developed } \\
\text { imminent symptoms }\end{array}$} \\
\hline & $\mathbf{N}$ & $\%$ & $\mathbf{N}$ & $\%$ & $\mathbf{N}$ & $\%$ & $\mathbf{N}$ & $\%$ \\
\hline Lateral location & 9 & 64.3 & 23 & 67.6 & 8 & 61.5 & 24 & 68.6 \\
\hline Central location & 5 & 35.7 & 11 & 32.4 & 5 & 38.5 & 11 & 31.4 \\
\hline Total & 14 & 29.1 & 34 & 70.9 & 13 & 27.1 & 35 & 72.9 \\
\hline
\end{tabular}

Severe preeclampsia was more common in lateral location. Fisher's exact test was used and no significant difference was noted ( $\mathrm{p}=0.82$ ).

Table 8: Abnormal parameters in preeclampsia.

\begin{tabular}{|lll|}
\hline Abnormal parameters in preeclampsia & $\mathbf{N}$ & Percentages $(\%)$ \\
\hline Thrombocytopenia (count $<\mathbf{1}$ L/cc) & 4 & 8.3 \\
\hline Increased liver enzymes- HELLP*syndrome & 5 & 10.4 \\
\hline Elevated renal parameters & 0 & 0 \\
\hline Urine albumin & & \\
\hline $4+$ & 3 & 6.25 \\
\hline $3+$ & 7 & 14.58 \\
\hline $2+$ & 20 & 41.66 \\
\hline $1+$ & 8 & 16.66 \\
\hline
\end{tabular}

*HELLP-Haemolysis, elevated liver enzymes, low platelets

Table 9: The predictive factors of location of placenta for development of preeclampsia.

\begin{tabular}{|lllll|}
\hline Variables & $\begin{array}{l}\text { Patient developed } \\
\text { preeclampsia, }(\mathbf{n = 4 8})\end{array}$ & $\begin{array}{l}\text { Patient not developed } \\
\text { preeclampsia, }(\mathbf{n = 1 0 2})\end{array}$ & P value & $\begin{array}{l}\text { Relative risk with } \\
\text { 95\% CI }\end{array}$ \\
\hline $\begin{array}{l}\text { Lateral location of placenta, } \\
(\mathbf{n = 5 4 )}\end{array}$ & 32 & 22 & $<0.0001 *$ & $3.5(2.1$ to 5.8$)$ \\
\hline $\begin{array}{l}\text { Central location of placenta, } \\
(\mathbf{n = 9 6 )}\end{array}$ & 16 & 80 & & \\
\hline
\end{tabular}

Table 10: Predictive factors derived from the above $2 \times 2$ contingency table.

\begin{tabular}{|lll|}
\hline Parameters & Statistics $(\%)$ & 95\% Confidence interval \\
\hline Sensitivity & 66.6 & 0.51 to 0.79 \\
\hline Specificity & 78.4 & 0.69 to 0.85 \\
\hline Positive predictive value & 59.2 & 0.45 to 0.72 \\
\hline Negative predictive value & 83.3 & 0.74 to 0.9 \\
\hline Likelihood ratio & 3.09 & --- \\
\hline
\end{tabular}

Thus, women with lateral location of placenta have 3.09 times the likelihood of developing preeclampsia compared with women with central location of placenta.

\section{DISCUSSION}

In this study, 150 patients were registered. Of the 150 patients, 48 developed preeclampsia with an incidence of
$32 \%$ and is comparable with studies done by Sumathi et al and Chandra et al with the incidence of $48 \%$ and $52 \%$ respectively. ${ }^{19,20}$ Women of different age group were included in the study group. The $60.7 \%$ were in the age 
group of 20-25 years. Central as well as lateral location of placenta was also common in the age group of 20-25 years and this makes our study comparable with Kofinas et al whose mean maternal age with both central and lateral location of placenta was 23.9 with a $\mathrm{p}=1.00 .{ }^{18}$ Among the women who developed preeclampsia, $52.1 \%$ were in the age group of 20-25 years. In the study by Chandra et al the majority of patients were in the age group of 21-25 years and the incidence of central and lateral location of placenta was common in the age group of 21-25 years. ${ }^{20}$

Age distribution of women who developed preeclampsia and in our study women of 20-25 years were more prone to develop preeclampsia $(n=25)$ with a frequency of $52.1 \%$. It is comparable to the study done by Kore SJ et al where the frequency of preeclampsia among women in the age group of 21-25 years was $41 \% .^{21}$ In our study, $34 \%$ were primi-gravidas and $66 \%$ were multigravidas which is comparable to $37.55 \%$ in primigravida, $62.45 \%$ in multigravida in study by Pai Muralidhar et al and Kore et al study reported as primigravida-34.5\%, multigravida$65.5 \% .^{22,21}$

The distribution of type of placenta in the study population shows $64 \%$ of women had central location of placenta and $36 \%$ of women had lateral location of placenta. In our study, development of preeclampsia in lateral placental location was $66.66 \%$ with $\mathrm{p}<0.0001$ which is statistically significant. Relative risk with $95 \%$ CI shows that women with lateral location of placenta have 3.5 times the risk of developing preeclampsia. It is comparable to $74 \%$ with $\mathrm{p}<0.03$ in Kofinas et al study, $81.7 \%$ with $\mathrm{p}<0.001$ in Sumathi et al study, $74 \%$ with $\mathrm{p}<0.0001$ in Pai Muralidhar et al study and $59.38 \%$ with $\mathrm{p}<0.001$ in Kore et al study. ${ }^{18,19,22,21}$

Out of the 48 women who developed preeclampsia in the study group, $70.9 \%$ developed non-severe preeclampsia and $29.1 \%$ developed severe preeclampsia. In our study, both severe $(66.7 \%)$ as well as non-severe preeclampsia $(67.6 \%)$ was common among women with lateral location of placenta. It is comparable to development of non-severe preeclampsia in $69.3 \%$ in Sumathi et al study and $52 \%$ in Chandra et al study and development of severe preeclampsia in $91.8 \%$ in Sumathi et al and $76.9 \%$ in Chandra et al study. ${ }^{19,20}$ Among the 48 women who developed preeclampsia, $27.1 \%(n=13)$, presented with imminent symptoms. In our study, $20.8 \%$ of women with severe preeclampsia presented with proteinuria. $10.8 \%$ of women presented with HELLP syndrome, which is comparatively higher with the incidence of $2.5 \%$ in the study by Sumathi et al. ${ }^{19}$. Comparison of predictive value of placental laterality in present study with other studies women with lateral location of placenta has 3.09 times the likelihood of developing preeclampsia compared with women with central location of placenta. Our study had a sensitivity of $66.6 \%$ which was comparable with $59.38 \%$ in study by Kore et al $73 \%$ in Pai Muralidhar et al $66.6 \%$ in Kakkar, Sandhya et al study study. ${ }^{21-24}$ The specificity of our study was $78.4 \%$ which correlates well with $76.67 \%$ in study done by Sumathi et al. ${ }^{19}$ The positive predictive value of our study was $59.2 \%$ which was higher when compared to $35.54 \%$ in study by Sumathi et al $46 \%$ in Kofinas et al study and correlated well with $51 \%$ in Pai Muralidhar et al study. ${ }^{19,18,22}$ The negative predictive value of our study is $83.3 \%$ which correlates well with the studies done by Sumathi et al $(88.05 \%)$ and Kofinas et al (90\%). ${ }^{19,18}$ Thus, placental position is an easy non-invasive test to predict preeclampsia.

When placenta is laterally located, in the majority of the cases, the uteroplacental blood flow needs are met primarily by one of the uterine arteries with some contribution from the other uterine artery via collateral circulation. The degree of collateral circulation may not be same in all women and deficient contribution may facilitate the development of preeclampsia. This is the limitation of this prediction test.

\section{CONCLUSION}

The study shows that placental location determined by ultrasonogram between 18-24 weeks of gestation is an excellent screening tool for the prediction of preeclampsia among numerous screening test. This test is ideal because it is simple, easy to perform, inexpensive, part of the anomalies scan performed, non-invasive and convenient for the patient. Lateral placentation helps to identify the population who is at greatest risk and those requiring careful obstetric management to achieve a more favourable outcome and to decrease the maternal and perinatal morbidity and mortality associated with preeclampsia.

\section{ACKNOWLEDGEMENTS}

Author would like to thanks to dean, Pudukottai medical college and hospital, Pudukottai, India for allowing me to do this study and utilizing the institutional facilities. I would also like to thank all the medical and para-medical staffs who have helped me to complete this study. A special thanks to all the patients who willingly co-operated and participated in this study.

Funding: No funding sources

Conflict of interest: None declared

Ethical approval: The study was approved by the Institutional Ethics Committee

\section{REFERENCES}

1. Cunningham FG, Leveno KJ, Bloom SL, Dashe JS, Hoffman BL, Casey BM et al. Williams obstetrics, $25^{\text {th }}$ edition; Hypertensive Disorders. McGraw-Hill Education. 2018;710-28.

2. Martin JN Jr, Owens MY, Keiser SD. Standardized Mississippi protocol treatment of 190 patients with HELLP syndrome: slowing disease progression and preventing new major maternal morbidity. Hypertension in pregnancy. 2012;31(1):79. 
3. Walker JJ. Current thoughts on the pathophysiology of preeclampsia/eclampsia. In Studd J. Progress in obstetrics ang gynaecology. Edinburgh: LivingstoneChurchill. 1998;177-88.

4. Myatt L, Clifton RG, Roberts JM. First-trimester prediction of preeclampsia in nulliparous women at low risk. Obstet Gynecol. 2012;119(6):2012a.

5. Myatt L, Clifton RG, Roberts JM. The utility of uterine artery Doppler velocimetry in prediction of preeclampsia in a low-risk population. Obstet Gynecol. 2012;120(4):815.

6. Usha K, Sheriar NK. OBG in perspective, pregnancy induced hypertension. Orient longman Publications, Endocr Jr. 2009;56(8):921-34.

7. Dutta DC. Text book of obstetrics. $8^{\text {th }}$ edition, Chapter 17; Hypertensive disorders in pregnancy. Central Publishers. 2016;221-42.

8. Thobbi VA, Anwar A. A study of maternal morbidity and mortality DUE to Pre-eclampsia and eclampsia. J Med Sci. 2017;10(3):174-9.

9. Arias F, Bhide AG. Arias' practical guide to high-risk pregnancy and delivery, $4^{\text {th }}$ edition; Hypertensive disorders in pregnancy. 2019;186-232.

10. Worley LC, Hnat MD, Cunningham FG. Advanced extrauterine pregnancy: diagnostic and therapeutic challenges. Am J Obstet Gynecol. 2018;198(3):297:e1.

11. Volhard F. Die doppelseitigen haematogenen Nierener krankungen. Berlin Springer. 1918.

12. Cunningham FG, Leveno KJ, Bloom SL. Williams obstetrics, 22 $2^{\text {nd }}$ ed. New York: McGraw-Hill. 2005;761-808.

13. Fleischer A, Schulman H, Farmakides G. Uterine artery Doppler velocimetry in pregnant women with hypertension. Am J Obstet Gynecol. 1986;154:80613.

14. Schulman H, Winter D, Farmakides G. Pregnancy surveillance with Doppler velocimetry of uterine and umbilical arteries. Am J Obstet Gynecol.1989;160:192-6.

15. Campbell S, Bewbey $\mathrm{S}$, Cohen-overbeek $\mathrm{T}$. Investigation of the uteroplacental circulation by Doppler ultrasound. Semin Perinatol. 1987;11:362.

16. Beek VE, Peters LLH. Pathogenesis of preeclampsia. A comprehensive model. Obstet Gynaecol survey. 1998;53(4):233-9.

17. Mosimann B, Wagner M, Poon LC. Maternal serum cytokines at 30-33 weeks in the prediction of preeclampsia. Prenat Diagn. 2013;33(9):823.

18. Kofinas AD, Penry M, Swain M. Effect of placental laterality on uterine artery resistance and development of preeclampsia and intrauterine growth retardation. Am J Obstet Gynecol. 1989;161:153-69.

19. Sumathi N, Pavithra GR. Placental laterality-A simple yet reliable Predictor of Pre-Eclampsia an ultrasonic prospective study. J Dental Med Sci. 2016;15(10):116-21.

20. Chandra K, Maheshwari S. Placental laterality: As a predictor for the development of pre-eclampsia. J Dental Med Sci. 2016;15(06):06-10.

21. Kore SJ et al. Int J Reprod Contracept Obstet Gynecol. 2016;5(5):1433-7.

22. Pai Muralidhar V. Placental laterality by ultrasounda simple yet reliable predictive test for preeclampsia. J Obstet Gynecol India. 2005;55:431-3.

23. Kakkar T, Singh V, Razdan R. Placental laterality as predictor of development of preeclampsia. J Obstet Gynaecol India. 2013;63(1):22-5.

24. Sandhya K, Madhavi GB, Chandramathi M. Placental laterality as predictor of development of preeclampsia. Am J Phytomed Clin Ther. 2015;3(3):231-6.

Cite this article as: Raji C, Sundaram A, Shenbagam G. Prospective cohort study in relation of placental location and risk of developing preeclampsia in a tertiary care hospital. Int J Reprod Contracept Obstet Gynecol 2022;11:759-64. 